ROCZNIKI HUMANISTYCZNE

Tom LXVIII, zeszyt 1 - 2020

DOI: http://dx.doi.org/10.18290/rh.20681-7

WOJCIECH KUDYBA

\title{
JANA POLKOWSKIEGO WIERSZE-ROZMOWY Z HERBERTEM I RÓŻEWICZEM
}

Choć przylgnęły do Jana Polkowskiego etykiety „poety stanu wojennego” czy też „poety historii”", warto podkreślić fakt, że ogromną część jego twórczości wypełniają nie tyle glosy do wydarzeń historycznych, ile raczej różnego rodzaju nawiązania do dzieł europejskiej kultury. Czeka na swego badacza zarówno wielokrotnie tematyzowana przez pisarza muzyka (zwłaszcza Bacha i Mozarta), jak i plastyka (między innymi ekfrazy dzieł Vermmera i Signorellego). Opracowania nie doczekały się również dialogi Polkowskiego z tradycją literacką, choć przecież autor Elegii z Tymowskich Gór wielokrotnie uobecnia w swych wierszach nie tylko postaci ważnych dla niego autorów pochodzących z różnych epok - od starożytności po współczesność - ale także podejmuje w swoich lirykach wyrafinowaną grę intertekstualną z wieloma pisarzami, przekładając, cytując, parafrazując fragmenty ich utworów lub aluzyjnie odnosząc się do ich twórczości. Ze szkiców krytycznych, poświęconych poezji Polkowskiego, wyłania się ogromne, dotąd niezagospodarowane badawczo pole relacji tekstów pisarza z twórczością autorów polsko-, anglo-, rosyjsko- czy też niemieckojęzycznych. Uwagi Mariana Stali skłaniają np. do refleksji nad obecnymi w wierszach Polkowskiego nawiązaniami do twórczości Paula Celana:

Prof. dr hab. WOJCIECH KUDYBA - kierownik Katedry Polskiej Literatury Współczesnej i Krytyki Literackiej na Wydziale Nauk Humanistycznych Uniwersytetu Kardynała Stefana Wyszyńskiego w Warszawie; e-mail: w.kudyba@uksw.edu.pl

${ }^{1}$ Pojawiają się one między innymi w następujących opracowaniach: M. INGLOT, $O$ poezji stanu wojennego, ,Język Polski w Szkole Średniej” 1992-1993, nr 1; D. PAWELEC, Poezja stanu wojennego. Przymiarka do tematu, „Postscriptum” 1992, nr 2; A. FIUT, W potrzasku (O poezji stanu wojennego), w: TEGOŻ, Pytania o tożsamość, Kraków 1995. 
Celanowskie tematy - ciemności, pustki, wykorzenienia, nicości, obcości w świecie - tematy wspólne katastroficznym i egzystencjalizującym światoodczuciom, buduja także w Pańskiej poezji przejmujące poczucie zagłady wartości $[\ldots]^{2}$.

Paweł Próchniak z kolei zachęca do śledzenia aluzji do twórczości Giennadija Ajgiego i Aleksandra Wata, pojawiających się we wczesnych lirykach autora Drzew

Wat i Ajgi to poeci ważni dla autora Elegii z Tymowskich Gór. I wolno może powiedzieć, że to od spojrzenia w ciemność przez nich zapisaną Jan Polkowski rozpoczyna swoją poetycką drogę ${ }^{3}$.

Jan Błoński pisał o widocznych w utworach Polkowskiego echach lektury Yvana Golla, Ryszarda Krynickiego i Czesława Miłosza ${ }^{4}$. Na podobny krąg inspiracji młodego pisarza wskazywali również inni badacze ${ }^{5}$. Dodajmy, że osobnej refleksji domaga się również Polkowski - tłumacz poezji rosyjskiej. W ostatnich swoich zbiorach wierszy autor Gorzkiej godziny publikuje przecież interesujące przekłady wierszy Osipa Mandelsztama, wspomnianego Giennadija Ajgiego, a także Iwana Bunina i Fiodora Tiutczewa. Powtórzmy: twórczość Jana Polkowskiego jako obszar nawiązań intertekstualnych domaga się monografii. Na co najmniej studium zasługują również uobecnione przez poetę nawiązania do pozaliterackich tekstów kultury - muzycznych i plastycznych.

Realizacja tak zarysowanych zadań ze zrozumiałych względów przekracza ramy niniejszego artykułu. Nie tracąc nadziei na to, że nie zabraknie badaczy, którzy je podejmą, chciałbym tymczasem przyjrzeć się kilku tekstom, które można nazwać wierszami-rozmowami, toczonymi przez autora Głosów z dwoma niewymienionymi dotąd pisarzami. Nazwisko pierwszego z nich nie będzie zaskoczeniem. W świadomości czytelników Polkowskiego od dawna utrwaliło się przecież przekonanie o związkach łączących go ze Zbigniewem Herbertem ${ }^{6}$.

\footnotetext{
${ }^{2}$ M. Stala, List do Jana Polkowskiego, w: W mojej epoce już wymieram. Antologia szkiców o twórczości Jana Polkowskiego (1979-2017), red. J.M. Ruszar, I. Piskorska-Dobrzeniecka, Kraków 2017, s. 57.

${ }^{3}$ P. PróchniaK, Polkowski: $w$ doskonatej ciemności, w: W mojej epoce już wymieram, S. 181.

4 J. BŁońsKI, Język wtaściwie użyty. O poezji Jana Polkowskiego, „Res Publica” 1987, z. 3 , s. 39 .

${ }^{5}$ Por np. M. Stala, List; A. MaZUR, Najwspanialszy ze smutków Europy, w: W mojej epoce już wymieram, s. 171-172; J. MIELNICZUK, Dawanie świadectwa - Herbert, Polkowski, Świetlicki, „Polonistyka” 1999, nr 4, s. 240-245.

${ }^{6}$ Por. między innymi D. PAwELEC, Oko smoka, w: W mojej epoce już wymieram, s. 101; W. BoLECKI, Poezja polska po 13 grudnia 1981 r., „Almanach Humanistyczny” 1984, nr 1-2, s. 205-206.
} 
Zwrócono uwagę na wspólny obu poetom program poezji etycznej, charakterystyczną właśnie dla nich pasję przyświadczania podstawowym wartościom i wiarę w ocalającą moc kultury, oraz na ciekawą grę intertekstualną, zainicjowaną przez młodszego pisarza w wierszu Przestanie pana $X^{7}$. O tym, że autor Przesłania Pana Cogito był dla Polkowskiego autorytetem moralnym, możemy dowiedzieć się z obszernego wywiadu, jaki pisarz udzielił Piotrowi Legutce ${ }^{8}$ :

Herbert był najzwyczajniej wierny wartościom, dziedzictwu kultury, losowi wspólnoty narodowej i nigdy nie opowiedział się po stronie choćby najbardziej obiecującego, postępowego czy nowoczesnego zła. Budował w języku polskim lojalność wobec moralnej mądrości, fundamentów tradycji i dobrego smaku. Nie prowadził z odwilżowym Szmaciakiem i liberalnym Gnomem gry o sławę, stypendia i posady za cenę poparcia lub chociaż przyzwolenia na sowiecką okupację Polski. W odróżnieniu od Różewicza i Miłosza przez większość życia nie pisał wierszy w pierwszej osobie. Stosował lirykę roli, budował racjonalność, historiozoficzny sens i analityczny dystans, a mimo to jego poezja niesie w sobie dramatyczne napięcie swojego czasu i wydaje mi się spleciona $\mathrm{z}$ dramatem drugiej połowy $\mathrm{XX}$ wieku. Ten, moim zdaniem, pozorny dystans do współczesności wzmacniał zapładniające napięcie między polskim losem a doświadczeniem uniwersalnym, pogłębiał sensy wierszy, których kształt nigdy nie otarł się o „pianę gazet”. Jeden z krytyków powiedział, że nie lubi Herberta, bo jest chłodny, anonimowy, pozbawiony emocji. To nieporozumienie, bo chłód Herberta jest pozorny. To liryka pisana na najwyższej strunie, ale pozbawiona egzaltacji i narcystycznych żali. Posługując się uniwersalną przypowieścią, dociera do zakamarków indywidualnego losu (s. 49).

Pada w cytowanym fragmencie także nazwisko Tadeusza Różewicza. W kolejnym akapicie cytowanej rozmowy autor przeciwstawia Herbertowską troskę o wspólnotę pokrzywdzonych eskapistycznej postawie autora Niepokoju:

Różewicz sumiennie uciekał od Polski, chował się przed pamięcią i chyba również przed miłością. Prawdopodobnie nie miał nadziei, że okupacja sowiecka może upaść w przewidywalnym czasie. [...] Było w tej postawie coś depresyjnego, godnego współczucia. Jakaś czarna rezygnacja (tamże, s. 49-50).

Grażyna Halkiewicz-Sojak, zauważając wspólny Polkowskiemu i Różewiczowi motyw „antypoezji”, mocno podkreśla właśnie odrębność aksjologicznego horyzontu twórczości obu pisarzy:

\footnotetext{
${ }^{7}$ Por. między innymi J. MielniczuK, Dawanie świadectwa, s. 241.

${ }^{8}$ Książka, choć złożona, dotąd nie została wydana. Ma tytuł Ryzyko bycia Polakiem. Korzystałem z komputeropisu w formacie PDF. Dziękuję Autorowi za użyczenie mi tego tekstu.
} 
Dla Różewicza „śmierć poezji”jest naturalną konsekwencją śmierci podstawowych humanistycznych wartości. W świecie pozbawionym wartości sztuka w ogóle, a poezja w szczególności, traci swe naturalne źródła kulturowe, wyrodnieje i znika. [...] Polkowski inaczej dochodzi do własnej formuły „niepoezji”. Nie kwestionuje istnienia wartości nadających sens życiu człowieka i życiu sztuki, chociaż dostrzega, że są one zagrożone. Zagrożenie wynika przede wszystkim z zafałszowania języka, niezdolnego wyrażać prawdy istotne?.

Czy zatem odnosząc poezję Polkowskiego do dokonań Zbigniewa Herberta skazani jesteśmy wyłącznie na śledzenie analogii? Czy każda próba skonfrontowania wierszy ,poety stanu wojennego" z utworami autora Czerwonej rękawiczki musi być opisem antagonizmu? Uważna lektura wierszy Polkowskiego uniemożliwia łatwe uogólnienia. Ostatnie jego książki - tj. dokonany przez poetę i poprzedzony obszernym wstępem wybór wierszy Tadeusza Różewicza $^{10}$ oraz tom liryków Rozmowy z Różewiczem ${ }^{11}$ - zdają się mocno utrudniać pospieszne rozstrzygnięcia.

Zacznijmy więc od niespiesznej lektury wiersza Przestanie pana $X$ :

Ocalałeś nie po to żeby dać świadectwo

które jak dym z odrzuconej ofiary

nie chce opuścić płonących miast

Twoje ciało oto początek i koniec czasu

I niech nie będzie poranionym archiwum

dla kilku wierszy lub bajek marzycieli

i głupców

Przeżyłeś nie po to żeby świadczyć

przeciwko niemu świat jest zbyt bliskim krewnym

twoich dzieci

Wszystkie drogi prowadzą

klucząc do miejsca w którym układasz się

do sprawiedliwego snu

Historia ma swoje prawa dlatego bez egzaltacji

z perspektywy tysiącletniej cywilizacji patrz

jak mały naród ginie

ja duszą się jego ostatnie pokolenia

Ale nie trać nadziei

może nie obudzisz się za ostrą bramą

\footnotetext{
${ }^{9}$ G. HALKIEwICZ-SoJAK, A jednak to poezja, w: W mojej epoce już wymieram, s. 51.

${ }^{10}$ T. RóżEWICZ, I znów zaczyna się przeszłość, wybór i wstęp J. Polkowski, Warszawa

11 J. POLKOwsKi, Rozmowy z Różewiczem, Kraków-Warszawa 2019.
} 2018. 
więzienia $\mathrm{z}$ nieregularną dwuramienną gwiazdą

wszytą w skórę

może nie dożyjesz tej chwili może umrzesz

przed narodzeniem się $\mathrm{w}$ narodzie wybranym

do zagłady

Zanim znajdą cię za miastem w mundurze

Robotnika lub studenta filozofii

Z twarzą przykrytą liberalną Polityką

opisującą faszystowskie praktyki

południowoamerykańskiej policji

Zanim zrozumiesz obelgę: Żyd!

Albo: polaczek!

Idź bądź wierny

fladze z biało-czarnego drutu

i generałom

swojej powszedniej modlitwy ${ }^{12}$

Tytuł utworu Polkowskiego nawiązuje do jednego z najbardziej znanych i najczęściej cytowanych wierszy Zbigniewa Herberta - Przestania Pana Cogito. Adresatem lirycznej wypowiedzi młodszego poety nie jest jednak Pan Cogito, lecz anonimowy pan X. Od razu cisną się zatem na usta pytania, czym różnią się ci dwaj bohaterowie i czy Polkowski kieruje swoją wypowiedź do takiej samej osoby, jaka pojawia się w tekście Herberta? Zostawmy je na razie bez odpowiedzi, zwróćmy natomiast uwagę na fakt, że cały wiersz Polkowskiego składa się z mikrocytatów z Herbertowego tekstu. Autorzy opracowań poświęconych Przestaniu pana $X$ pisali o tym wielokrotnie. Zarówno Ewa Sławkowa, jak i Julia Mielniczuk cierpliwie odsłaniają sieć zapożyczeń i aluzji, która stanowi konstrukcyjny szkielet wiersza młodszego pisarza. Obie interpretatorki podkreślaja przy tym, że liryk Polkowskiego nie jest ani uwspółcześniającym rozwinięciem Przestania Pana Cogito, ani też komentarzem do niego. Zwracają uwagę na emocjonalny dystans Polkowskiego wobec Herbertowego arcywiersza, różnią się jednak między sobą w ocenie tego dystansu. Ewa Sławkowa pisze o gorzkiej ironii młodego poety ${ }^{13}$, Julia Mielniczuk o tym, że wiersz młodego poety to „krytyczny pastisz” ${ }^{14}$ utworu

\footnotetext{
12 J. Polkowski, Gdy Bóg się waha. Poezje 1977-2017, red. J.M. Ruszar, Kraków 2017, s. $40-41$.

${ }^{13}$ E. SŁawKowa, Jan Polkowski „Przestanie pana X” - przejmujace świadectwo epoki. Propozycja interpretacyjna dla klasy IV liceum i V technikum, „Język Polski w Szkole Średniej” 1993, z. 1, s. 53-54.

14 J. MielniCZuK, Dawanie świadectwa, s. 241.
} 
Herberta. Podstawową różnicą, widoczną na samej powierzchni obu tekstów, jest - zdaniem interpretatorów - odmienna perspektywa, z której podmiot ogląda rzeczywistość. Jak pisze Mielniczuk: „Polkowski [...] zmienia optykę i od szerokiej perspektywy historyczno-kulturowej [podstawowej w wierszu Herberta] przechodzi do perspektywy jednostki i konkretnej sytuacji politycznej"15. Tadeusz Patrzałek ujmuje ten fakt następująco:

Myślę, że bardziej ten właśnie - uniwersalizujący i przeabstrahowany - obraz recepcji, niż bezpośrednio oddziaływanie słowa wielkiego poety, wywołały odruch sprzeciwu poety rozpoczynającego. Bo tak, jako poetycką polemikę czytam wiersz Polkowskiego, którego osobowość poetycka jakby zrosła się z rzeczywistością najbliższą i najcodzienniejszą [...]. Gdy tak trudno „głęboko: oddychać”, jakże więc dawać pouczenie: „Bądź wierny. Idź”. Jakże „dawać świadectwo” z myślą o przyszłych pokoleniach, „,bez egzaltacji, z perspektywy tysiącletniej cywilizacji”, gdy się widzi, ,jak mały naród ginie, jak duszą się jego ostatnie pokolenia"? ${ }^{16}$

Przyjrzyjmy się nieco bliżej tekstowi Polkowskiego. Rozpoczynają go słowa: „ocalałeś nie po to żeby dać świadectwo”, a nieco dalej pojawiają się one w innym kształcie: „przeżyłeś nie po to żeby świadczyć”. Odnoszą się one do jednego ze zdań zawartych w Przestaniu Pana Cogito. Herbert pisze bowiem: „ocalałeś nie po to aby żyć / masz mało czasu trzeba dać świadectwo"17. Różnica pomiędzy obydwoma przywołanymi frazami jest aż nadto widoczna. Jeśli Zbigniew Herbert kreśli przed nami wizję życia, które ma być heroicznym - bo gotowym na śmierć - świadectwem wierności podstawowym wartościom, to Polkowski opisuje życie, którego celem nie jest ani wierność, ani dawanie świadectwa, ani w ogóle jakikolwiek heroizm. Co więc ma być celem egzystencji człowieka, do którego zwraca się podmiot wiersza Polkowskiego? - Wydaje się, że samo biologiczne przetrwanie ciała. Bohater, do którego zwraca się ktoś, kto mówi w wierszu, uważa swe własne ciało za miarę wszystkiego, nie ma zatem zamiaru w jakikolwiek sposób go narażać - np. na pobicie podczas demonstracji. Ma natomiast szczerą chęć zapewnić mu odpoczynek i ,sprawiedliwy sen”, bez względu na wszelkie uwarunkowania zewnętrzne, takie jak np. tragiczna sytuacja ginącego narodu. Czy wobec tego należy wysnuć wniosek, że Polkowski popiera postawę konformistyczną i odżegnuje się od jakichkolwiek form współczucia wobec ofiar totalitarnej

\footnotetext{
15 Tamże.

16 T. PAtrZaŁeK, Dwa przestania, „Polonistyka” 1992, nr 4, s. 236.

${ }^{17}$ Z. Herbert, Przestanie Pana Cogito, w: Z. Herbert, Pan Cogito, wyd. II poprawione, Wrocław 1993, s. 88.
} 
przemocy? - Oczywiście, nie. W świetle innych utworów poety widzimy wyraźnie, że jego Przestanie pana $X$ ma charakter ironiczny. Zwraca się przeciwko konformistom, chłostając ich lękliwą i uległą postawę biczem sarkazmu.

Julia Mielniczuk twierdzi jednak inaczej. Uważa, że autor Przesłania pana X krytykuje Herberta i chwali zwykłe, codzienne, cielesne życie. Jako podstawową różnicę między lirykami Herberta i Polkowskiego wskazuje odmienną perspektywę, z której podmiot ogląda rzeczywistość. Pisze zatem: „Polkowski [...] zmienia optykę i od szerokiej perspektywy historyczno-kulturowej [podstawowej w wierszu Herberta] przechodzi do perspektywy jednostki i konkretnej sytuacji politycznej"18. Nieco dalej zaś dodaje:

Sam heroizm i niezmienne trwanie przy uniwersalnych wartościach zdawały się poecie nie wystarczać przy tak dramatycznym, a zarazem dynamicznym rozwoju wydarzeń w kraju. Dlatego zaprzeczał Herbertowi mówiąc: „Ocalałeś nie po to żeby dać świadectwo”. Jego Przesłanie nie jest uaktualnieniem myśli Pana Cogito, lecz w swej wymowie zakwestionowaniem celowości pozostawiania takiego memento. Skoro nic się nie zmienia, a jeden totalitaryzm jest zastępowany przez kolejny, to po co świadczyć? [...] etos proponowany przez Pana Cogito okazał się nie na miarę czasów, w których żył pan X. U poety pojawiają się wątpliwości. Jakby na marginesie powinności patriotycznych rodziło się w nim pytanie o wartość życia jednostkowego, wyznaczonego nie trwaniem w kulturze, lecz granicami śmiertelnego ciała ${ }^{19}$.

Zdaniem komentatorki, Polkowskiemu bliżej jest do poety, który stał się symbolem poezji niezaangażowanej - tj. do Marcina Świetlickiego. Według Mielniczuk Polkowski, tak jak Świetlicki, nie chce rezygnować „z prywatności życia dla dawania świadectwa czasów"20. Czy rzeczywiście tak jest? Czy interpretacja Mielniczuk nie prowadzi nas na manowce? Aby odpowiedzieć na tak postawione pytanie, zacznijmy od najbardziej podstawowych ustaleń. Wiersze Herberta i Polkowskiego korzystają bowiem z konwencji właściwych liryce apelu, w obu dominuje tok apostroficzny. Oznacza to, że każdy z utworów kreśli wyraźny wizerunek adresata poszczególnych wezwań. Gdyby okazało się, że obaj poeci zwracają się do podobnego kręgu osób, różnice pomiędzy ich tekstami musiałyby dotyczyć przesłania wiersza. Tymczasem wiele wskazuje na to, że Polkowski wyobraża sobie swego adresata

\footnotetext{
18 J. MielniczuK, Dawanie świadectwa, s. 241.

19 Tamże, s. 242.

20 Tamże.
} 
zupełnie inaczej niż Herbert. Autor Przesłania Pana Cogito zwraca się przecież do kogoś, kto będzie zdolny udźwignąć ciężar etyki pozbawionej nadziei na doczesną nagrodę - do kogoś, kto spróbuje sprostać etosowi wierności najważniejszym wartościom (wpisanemu w osobowe wzory kultury Zachodu). Do kogoś, kto będzie zdolny ponieść trud świadectwa osobistej godności i niepodległości wobec zakusów historii i podszeptów strachu. Pan X - widzimy to od początku wiersza - jest kimś zupełnie innym. To ktoś niezdolny do przekroczenia horyzontu „małej stabilizacji”, jaką próbował oferować PRL. To ktoś, kto zapomniał o ideałach i moralnych obowiązkach, by żyć wyłącznie nadzieją na to, że nie stanie się ofiarą totalitarnej przemocy i tym samym ocali swój mały świat i swoje kruche ciało. To ktoś, kto próbuje uzasadnić swoją konformistyczną postawę prawami dziejów, które niekiedy obracają się przeciw niepokornym narodom, skazując je na zagładę. Ostrze sarkazmu, które wychyla się z tego wiersza, poeta kieruje w stronę takiej właśnie osoby.

Mielniczuk - wbrew swojej głównej tezie - trafnie zauważa zatem, że „,ironia [...] służy tu wyszydzeniu konformistycznej postawy wycofania się z zaangażowania opozycyjnego dla ochrony prywatnego bezpieczeństwa"21. Taką właśnie, sarkastyczną ironią poeta od początku utworu aż po jego finał smaga adresata swych apostrof. O czym miałby świadczyć ktoś, kto ograniczył swoją życiową przestrzeń do „miejsca snu” i zamknął horyzont swego życia w strategii biologicznego przetrwania? Prawdopodobnie wyłącznie o własnym konformizmie i niczym więcej... Jeśli pamiętamy o tym, że w języku poetyckim Polkowskiego sen zawsze otoczony jest negatywnymi konotacjami, to bez trudu rozpoznamy gryzącą ironię sformułowania „sprawiedliwy sen”. „Sprawiedliwość" bohatera tekstu polega przecież na całkowitej obojętności wobec tragedii wspólnoty, niszczonej przez totalitarny reżim. Jego „nadzieja” jest wyłącznie strachem. Jego „mądrość” - defetyzmem. Jego „wierność" - czytamy o tym w zakończeniu wiersza - jest biernością wobec opresji, zaś „modlitwa” - uległością wobec wojskowego reżimu. Sprzeciw Polkowskiego, pełna bólu i pasji niezgoda pisarza z całą mocą uderzają w opisanym wierszu nie w rygorystyczną etykę Herberta i jej kulturowe zaplecze, ale w pseudoetykę konformisty, w przedstawiciela gatunku, którego badacze kultury totalitarnej określili mianem homo sovieticus.

Zasadnicze różnice oddzielające utwór Polkowskiego od wiersza Herberta w niewielkim stopniu dotyczą więc wyboru postawy życiowej i ideałów walki $\mathrm{z}$ totalitaryzmem. Na pewno obaj poeci nieco inaczej formułuja jednak swoją

\footnotetext{
${ }^{21}$ Tamże.
} 
nadzieję na trwanie przy wartościach. Tekst Polkowskiego jest po prostu dużo bardziej pesymistyczny. Od początku Przestania pana $X$ jest jasne, że nadzieja, której Polkowski nie odrzuca, wydaje się w jego tekście dużo bardziej problematyczna niż wizja zamieszkania w mitach kultury, jaka wyłania się z utworu autora Potęgi smaku. Znaki, które mogłyby rozświetlać horyzont przyszłości, młody autor konsekwentnie opatruje przecież ironicznym nawiasem. Dzieje się tak zwłaszcza wtedy, gdy pojawia się pokusa sakralizacji ofiar stany wojennego lub samego umęczonego narodu. Wileńskie sanktuarium, Ostra Brama, jest u Polkowskiego tylko zwykłą bramą zakładu karnego. Nie ma też nic wzniosłego we frazie o narodzie wybranym, skoro przerzutnia przypomina, że chodzi o wybranie do zagłady. Flaga narodowa staje się w utworze Polkowskiego zwykłym zwojem drutu. Wiersze nazywa on (poeta!) bajkami marzycieli i głupców. Mielniczuk słusznie zwraca uwagę, że słowa o „generałach powszedniej modlitwy” to „wspomnienie rządów Wojskowej Rady Ocalenia Narodowego". Wydaje się, że poeta świadomie zderza w swoim tekście podstawowe elementy religijno-patriotycznej retoryki lat osiemdziesiątych z realiami policyjnego państwa i mentalnością zwolenników wojskowego reżimu. Estetycznym efektem tej konfrontacji jest sarkazm, który okrywa swym gorzkim tonem cały wiersz.

Oddając sprawiedliwość dotychczasowym komentatorom wiersza, powiedzmy zatem na koniec, że rozbieżności dotyczą też poetyki obu utworów. Tadeusz Patrzałek ma rację pisząc o odmienności estetyk obu twórców ${ }^{22}$. Wydaje się, że Polkowski rzeczywiście - trochę po różewiczowsku - znajduje się bliżej szarego, historycznego tu i teraz, unika charakterystycznego dla klasycyzmu dystansu wobec codziennych spraw i emocji, o wiele chętniej niż Herbert eksploatuje rozległe obszary prywatności. Co więcej: poczynione dotąd analizy pozwalają zauważyć fakt, że - inaczej niż Herbert, preferujący lirkę maski - o wiele częściej korzysta on z formy bezpośredniego lirycznego monologu, częściej zapisuje walkę sprzecznych uczuć.

Skąd jednak u Polkowskiego fascynacja wierszami Tadeusza Różewicza? Sam sposób stawiania takiego pytania wydaje się prowokacyjny, bo do niedawna nic o niej nie wiedzieliśmy. Sytuacja zmieniła się w chwili, gdy na rynku wydawniczym ukazał się tom I znów zaczyna się przeszłość. Autor obszernego wprowadzenia zaczyna od wyrazistej deklaracji:

\footnotetext{
22 T. PatrZaŁeK, Dwa przestania, s. 235.
} 
Twórczość Tadeusza Różewicza od końca lat 60. należy do moich częstych i ważnych lektur i jestem pewien, że również w przyszłości poeta pozostanie moim inspirującym rozmówcą, sprawcą ciągle nowych wzruszeń i trudnych do rozwikłania zagadek, bo przecież żaden wiersz nie ma końca. [...] Dzięki wierszom Różewicza pierwszy raz świadomie odczułem siłę słowa i próbowałem powtarzać w duchu zapisane przez poetę zdania - skondensowane, proste i jednocześnie ciemne, nieprzebyte, zdające się współbrzmieć z tajemnicą życia przygniatającą moją niepewną młodośćc ${ }^{23}$.

Cytowany fragment w swej zasadniczej części opisuje odczucia licealisty, mógłby więc zostać wzięty w nawias i spisany na karb młodzieńczej naiwności, która już niebawem zmieni się w spojrzenie opozycjonisty lat osiemdziesiątych, krytycznie oceniającego zarówno moralną postawę Różewicza, jak i jego literackie decyzje. W cytowanej wielokrotnie rozmowie z Piotrem Legutką natrafiamy przecież na opinię, która nie pozostawia co do tego najmniejszych wątpliwości:

[Różewicz] Demonstracyjnie oświadczał - nie obchodzi mnie „Solidarność”, nie obchodzi mnie dążenie do wolnej Polski. Co więcej, w jego utworach słychać było ironizowanie na temat tych, którzy podnosili głowę, chcieli zachować pamięć i twierdzili, że bez zasad moralnych również w naszych czasach nie sposób być ani pełnym człowiekiem ani artystą (s. 50).

Mogłoby się wydawać, że ten zdecydowany i wyrazisty sąd zamknie obszar dialogu Polkowskiego z autorem Szarej strefy, ale tak się nie stało. Być może postawa otwarta jest możliwa także wtedy, gdy towarzyszą jej kategoryczne oceny. W cytowanym wstępie do wyboru wierszy starszego poety autor Głosów opowiada w każdym razie o swym upartym poszukiwaniu płaszczyzn porozumienia z autorem Płaskorzeźby. Co więcej: właśnie w zdolności Różewicza do rozmowy - do dialogów ponad czasem i przestrzenią - dostrzega zasadniczą wartość jego liryki:

Wspólnotę z Różewiczem czuję do dzisiaj w wielu kwestiach, zwłaszcza wtedy gdy odczytuję rozmowy, które autor Liry Leopolda Staffa nieprzerwanie prowadzi z umarłymi (i z żywymi) twórcami. Napisałem „prowadzi”, bo te dialogi nie ucichły wraz ze śmiercia poety i będa rozbrzmiewały do końca świadomego istnienia świata. Radują mnie takie wiersze-rozmowy bez względu na to, czy zgadzam się z Różewiczem i czy cenię twórczość jego rozmówcy. Dzięki takim dyskusjom kultura, tożsamość i poszukiwanie sensu (sens poszukiwania) żyja

\footnotetext{
${ }^{23}$ T. RóżEWICZ, I znów zaczyna się przesztość, s. 5.
} 
ponad czasem. Zatrzymując się przy utworach poszukujących braterstwa lub wciągających w polemikę, zagłębiałem się w pamięć kultury, uczyłem odróżniać dobro od zła i mam nadzieję, że tak jak każdy czytelnik próbowałem być lepszym człowiekiem $^{24}$.

Czyżby więc to właśnie Różewiczowe wiersze-rozmowy stały się inspiracją ostatniego zbioru poetyckiego Jana Polkowskiego? Wiele na to wskazuje, bo choć dialogi z tradycją literacką są w omawianej poezji stosunkowo częste, to jednak zbiór Rozmowy z Różewiczem wyróżnia się na ich tle w sposób zdecydowany. W żadnym innym nie mamy przecież do czynienia z podobna kompozycją: Polkowski przepisuje wybrany wiersz Różewicza, a zaraz obok umieszcza swój utwór (czasem więcej niż jeden), będący swoistą odpowiedzią na słowa partnera rozmowy. Swoistą, bo przybiera ona różne formy. Czasem obcujemy ze sporem, czasem zaś z poszukiwaniem tego, co łączy, zawsze jednak - z elementami parafrazy. Polkowski dokonuje przekładu Różewiczowych obrazów na swój własny idiom poetycki. To specyficzne „tłumaczenie” oznacza postawę dialogową i wysiłek zrozumienia słów rozmówcy. Zarazem jednak $\mathrm{w}$ istotny sposób poszerza ono obszar możliwych znaczeń obydwu liryków, sprawia, że każdy z nich staje się czymś więcej niż pojedynczym tekstem. Oto przykład. Najpierw pojawia się wiersz Tadeusza Różewicza:

Poeta $w$ czasie pisania

Poeta w czasie pisania to człowiek odwrócony tyłem do świata do nieporządku rzeczywistości

Poeta w czasie pisania jest bezbronny łatwo go wtedy zaskoczyć ośmieszyć przestraszyć

wynurzył się wyszedł ze świata zwierzęcego na wędrownych piaskach widać ślady jego ptasich nóżek

\footnotetext{
${ }^{24}$ Tamże, s. 6.
} 
z oddali dochodzą jeszcze

głosy słowa

ziarnisty śmiech

kobiet

ale nie wolno mu

spojrzeć

za siebie

wyrzucony na powierzchnię

pusty

poniewiera się

po mieszkaniu

zakrywa twarz

na której maluje się zdumienie

błąka uśmiech

jeszcze nie potrafi

odpowiadać

na najprostsze pytania

słyszał

oddech wieczności

przyśpieszony

nieregularny ${ }^{25}$

Odpowiedzią Polkowskiego jest następujący utwór:

$$
* * *
$$

Poeta w czasie pisania

ukrywa się za ściana

śmierci

w utajonym jądrze

świata

w nasieniu

Boga

Poeta w czasie pisania

zanika wtapia się $\mathrm{w}$ tło

światła

nie można go wtedy

zabić

\footnotetext{
25 J. POLKOwSKI, Rozmowy z Różewiczem, s. 10.
} 


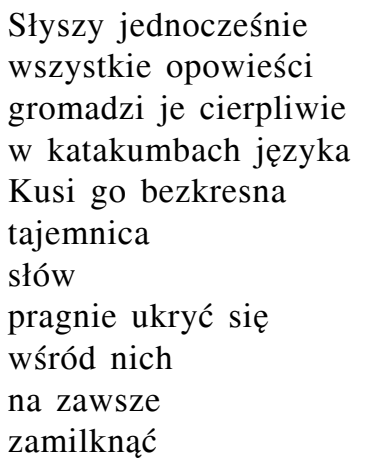

Wie że hałas zasypuje jego spowiedź więc $\mathrm{z}$ wysiłkiem osłania słabnący sens swojego czasu ślepy ślad losu

Bezsilnie broni się przed miłością do ciemnej mowy do ucieczki ${ }^{26}$

Od razu warto zwrócić uwagę na to, jak wiele łączy obydwa utwory. Jan Polkowski podejmuje ten sam temat i odwołuje się do tej samej konwencji gatunkowej. Tak jak Różewicz stara się obrysować słowami psychologię aktu twórczego, opisać ów szczególny stan, w którym znajduje się ,poeta w czasie pisania". W obu przypadkach mamy do czynienia nie tyle z osobistym wyznaniem, ile raczej z wysiłkiem obiektywizacji sądów i trudem uniwersalizacji przesłania. Celem Różewicza, później także Polkowskiego nie jest powierzenie czytelnikowi intymnych sekretów, lecz przedstawienie mu zasadniczych, chciałoby się nawet powiedzieć: istotowych cech „stanu poetyckiego”. Stylistyka obu tekstów i ich składnia są podporządkowane informacyjnej funkcji komunikatu. Kolejne strofoidy służą precyzowaniu treści. Fakt, że w obydwu lirykach definicyjne formuły mają charakter obrazowy i metaforyczny, niczego tu nie zmienia. Obydwa są poetycką definicją aktu twórczego.

Co o nim mówią i czy właśnie tu, na poziomie detali zaczynają się istotne różnice? Pierwszy człon definicji ,poeta w czasie pisania to...” w wierszu

\footnotetext{
26 Tamże, s. 11.
} 
Różewicza został uzupełniony rozmaitymi obrazami „oderwania” artysty od świata. Można je odczytywać w sensie potocznym, jako portrety roztargnienia, błąkania się po mieszkaniu, autor nadaje im jednak znaczenie dużo głębsze. Słowo 'świat' najpierw oznacza bowiem ten wymiar codzienności, który kojarzymy nie $\mathrm{z}$ poczuciem ładu istnienia, lecz doświadczeniem chaosu sprzecznych bodźców. Nieco dalej pojawia się strofoida o przekraczaniu świata naturalnego, zwierzęcego. „Przekraczanie” wydaje się w tym liryku słowem kluczem. Bohater Różewicza przekracza to, co naturalne i chaotyczne. Tym, co przekroczone, okazuje się cała naturalna czasoprzestrzeń, skoro autor mówi o oddechu wieczności. Bardzo blisko stąd do niektórych współczesnych teorii poezji. Myślę zwłaszcza o propozycji Stefana Sawickiego, który tak kończy swój esej:

Zawiera w sobie poezja intuicję całości, choćby i przez fragment doświadczanej. To pieśń przekraczającego siebie nieustannie człowieka.

Nie sposób nie zauważyć, że ta rzeczywistość absolutna, ujawniana, może przeczuwana, która zarysowuje się na horyzoncie poezji, jest bliska rzeczywistości obecnej w przeżyciu religijnym ${ }^{27}$.

Nie bez zdumienia spostrzegamy, że także przesłanie, jakie kieruje do nas Polkowski, nie przekracza ram opisanego wyżej sposobu pojmowania poezji. Również on zamyka w gęstych, sugestywnych metaforach doświadczenie przekraczania, tyle że ujmuje nieco inny aspekt tego procesu niż Różewicz. Pisze nie tyle o tym, co poeta porzuca, ile raczej o tym, ku czemu musi on zmierzać. Stąd właśnie topos schodzenia w głąb - ku jądru świata, w stronę tła światła, do matecznika opowieści, ku katakumbom języka, w stronę ich sedna. Jeśli jest to ucieczka, to taka, która oznacza odłączenie od rozpraszającego zgiełku doraźności i śmierci. Jeśli jest to droga, to prowadzi ona w stronę transcendencji. Czy zatem tekst młodszego poety jest rodzajem komentarza do wiersza antenata? - Raczej tak, warto jednak określić, o jaki rodzaj glosy mogłoby tu chodzić. Mamy przecież w wierszu Polkowskiego zestaw motywów i myśli, które znamy z innych jego wypowiedzi o języku - zarówno dyskursywnych, jak i poetyckich. Była już o tym mowa: autor Glosów dokonuje swoistej translacji wiersza Różewicza na język poetycki, który sam wypracował...

Nie oznacza to oczywiście, że Polkowski, komponując swój autorski wybór wierszy starszego kolegi, rezygnuje z prób ustalenia protokołu rozbieżności

${ }^{27}$ S. SAWICKI, Religijny horyzont poezji, w: TEGOŻ, Wartość. Sacrum. Norwid 2, Lublin 2007, s. 14-15. 
i wyznaczenia linii, poza którą porozumienie z autorem Czerwonej rękawiczki nie jest możliwe. Granicą okazuje się spójność postawy moralnej i światopoglądowej, będąca fundamentem etyki twórczości. Autor Pochodu duchów wydobywa pęknięcie obecne we wczesnej twórczości Różewicza - dostrzeżone także przez badaczy literatury ${ }^{28}$ :

Wiarygodność i spójność poetyckiej diagnozy podważają również inne fakty, a wśród nich zaangażowanie autora Uśmiechów w socrealizm. Uważam, że utwory opublikowane w tym okresie w istotny sposób zakłócają odbiór wcześniejszych wierszy, a nawet w jakimś sensie unieważniają twardą diagnozę o śmierci kultury i człowieczeństwa, które bez wyjątku uległo cywilizacji ludobójstwa. Kłopot polega na tym, że obfita socrealistyczna twórczość poety stała w fundamentalnej ideowej, moralnej i artystycznej sprzeczności z programowymi wierszami samego poety (Ocalony). Ich powstanie wydaje się raczej opierać na ideowym podglebiu diagnozy zawartej w wierszu. Do umartego. Oba te utwory (Do umartego i Ocalony) symbolicznie sąsiadują ze sobą na stronach 20 i 21 Niepokoju i są biegunami ideowymi dzielącymi świat Różewicza na dwie nieprzystające do siebie części. Jeden jest manifestem przystosowania i akceptacji świata, drugi krzykiem niezgody na obojętne przechodzenie obok zdechłej kultury, języka zła i kryzysu człowieczeństwa. Twórczość poety w każdym razie do 1956 roku dowiodła, że ani prochy umarłych ani krzyk mordowanych nie powstrzymały ofensywy życia, nie powstrzymały erupcji literackiej w stalinowskiej PRL ${ }^{29}$.

Osią sporu obu poetów okazuje się zatem ich stosunek do rzeczywistości wczesnego PRL. Rozmowy z Różewiczem nie eksponują socrealistycznych fascynacji tego ostatniego, ale też ich nie omijają. Autor Gtosów przypomina i komentuje tylko jeden spośród wielu tekstów starszego poety, wpisujących się w estetykę i poetykę socrealizmu:

Nie kładź mi rak na sercu

I

Nie kładź mi rąk na głowie nie kładź mi rąk na ustach na oczach i na sercu nie kładź mi rąk na sercu

${ }^{28}$ P. PIETRYCH, „Niepokój” - niemal zapomniany tom poetycki Tadeusza Różewicza z 1947 roku, „Pamiętnik Literacki” 2017, nr 2, s. 143-166.

${ }^{29}$ T. RóżEWICZ, I znów zaczyna się przyszłość, s. 15-16. 
W gromadzie Ciążeniec zatłukli na śmierć kijami Leona Maciejowskiego komunistę

II

Walili go po głowie walili go po ustach po oczach i po sercu zła krew mówili potem ręce umyli plamy z ubrań wytarli i myśleli że krew zmyli że tak łatwo zmywa się krew

\section{III}

Nie kładź mi rąk na głowie nie kładź mi rąk na ustach na oczach i na sercu Nie kładź mi rąk na sercu ${ }^{30}$.

Jak nietrudno się domyślić, przywołany wyżej utwór nie trafił do kanonu wierszy Różewicza, który konsekwentnie próbował wymazać ze swego obszernego dorobku cały socrealistyczny okres. Artystyczna miałkość i jednoznaczna wymowa kolejnych strof tekstu są aż nadto widoczne. Niełatwo dziś precyzyjnie wskazać źródła inspiracji poety, ale nie jest niemożliwe ustalenie obszaru, z którego czerpał. W krakowskim „Dzienniku Polskim” z soboty 27 listopada $1948^{31}$ natrafiamy na notkę zatytułowaną: „Banda reakcyjna zamordowała działacza wiejskiego PPR". Jej treść przedstawia się następująco:

Ofiarą napaści bandy reakcyjnej padł zasłużony działacz wiejskiej PPR, Maciejowski, rolnik z gromady Ciążeniec, pow. konińskiego. Ob. Maciejowski jako pełnomocnik gminy powracał $w$ tych dniach do domu $\mathrm{z}$ walnego zebrania gromadzkiego. Po drodze napadnięty został przez bandę reakcyjną i pobity do utraty przytomności. Skatowany przez bandytów dowlókł się po odzyskaniu przytomności do domu i tam skonał. Ob. Maciejowski liczył lat 54. Pozostawił żonę i 5 nieletnich dzieci.

Utwór Różewicza należy więc do długiej serii „,wierszy z gazet”, która rozwija się niemal do końca jego twórczości. W 1948 roku poeta mieszka w Krakowie

\footnotetext{
${ }^{30}$ J. Polkowski, Rozmowy z Różewiczem, s. 50.

${ }^{31}$ Korzystałem z wersji zdigitalizowanej: http://mbc.malopolska.pl/Content/90838/dp_1948 _325.pdf [dostęp: 16.10.2018].
} 
(w tymże roku odbiera Medal Wojska Polskiego). Źródłem cytowanego wiersza mógł być zatem krakowski „Dziennik Polski”? - Tego czy rzeczywiście był, niepodobna jednak dowieść. Być może nie, bo w cytowanej notatce brak imienia komunistycznego działacza i szczegółów zabójstwa - zatem informacji, które wykorzystuje pisarz. Jest w niej natomiast motyw sieroctwa pięciorga dzieci którego brakuje w wierszu. Wiadomość podana przez ogólnopolską agencję trafiła jednak przecież nie tylko do lokalnego dziennika - tak od Konina odległego. Pojawiła się ona zapewne we wszystkich gazetach krajowych i poeta mógł czytać notatkę zawierającą detale, których zabrakło w „Dzienniku Polskim”. Dokładne ustalenie źródła, z którego korzystał pisarz, nie wydaje się zresztą w tym przypadku najbardziej istotne. Ważniejsze jest co innego: to, jaka relacja łączy informację agencyjną $\mathrm{z}$ tekstem poetyckim. Wiele wskazuje na to, że liryk stanowi kontynuację tekstu publicystycznego - tzn. w żaden sposób nie wzbogaca jego treści. Czy jednak system, któremu służył komunistyczny działacz, był rzeczywiście niewinny? Tego nie dowiemy się z cytowanego utworu. Takie pytanie tkwi jednak u źródeł poetyckiej odpowiedzi Polkowskiego:

$$
* * *
$$

Kładę głowę na ziemi w celi zamykam przyszłość ryję pod cudzym grobem pod zmarzliną milczenia szukam guzików i zębów z których zbuduję dom

Kładę głowę na śmieciach rośnie z żyznych piszczeli los lat i smród słów Dziurawe czaszki rodzą lepią z prochów dzieci Niewinne ręce pokoleń zbierają wapno wiary w potoczystą niepamięć

Nicość kość kładzie na kości z kości wypada kula pieści marzenia kata szuka nowego świata ${ }^{32}$.

\footnotetext{
32 Tamże, s. 51.
} 
Ten przejmujący liryk zdaje się wyrastać z niezgody na zamazywanie prawdy historycznej i zacieranie granicy pomiędzy dobrem i złem. Kat jest w nim katem, a marzenia o nowym wspaniałym świecie - groźną utopią. Czaszki, piszczele, zęby i guziki stają się tu nieusuwalną pamiątką zbrodni komunizmu. Sa śladem zła i winy - zamazywanym, przemilczanym przez jednych, fundamentalnym dla innych. Zapomnienie o nich nie jest pozbawione wymiaru aksjologicznego i moralnego. Jak czytamy, brak takiego wymiaru oznacza pustkę. Niepamięć otwiera drogę procesowi nihilizacji wartości etycznych, zmienia świat w nicość. Ważnym kontekstem wiersza wydaje się następująca opinia o autorze Niepokoju:

Wszystko układało się dobrze, jednak poeta wspomina: śnili mi się pomordowani, których było więcej dokoła niż żywych. Pomordowani dzielili się na dwie kategorie. Na tych, których śmierć podlegała moralno-estetycznej refleksji, zamordowani przez Niemców przed 1944 rokiem i tych torturowanych i mordowanych przez Rosjan i ich agenturę w czasie wojny, a zwłaszcza po niej, między innymi na rogu ulic Kapucyńskiej i Podwale, gdzie siedzibę po Gestapo przejęło NKWD i UB, czyli pod nosem pisarzy mieszkających na ulicy Krupniczej w Krakowie. Czy to powtórne uśmiercenie i wymazanie z pamięci części ofiar i milcząca zgoda na nowe nie poddaje w wątpliwość wiarygodności i aksjologicznej spójności katastroficznych przemyśleń i estetycznych wniosków Różewicza? Opierały się przecież na rygoryzmie moralnym, proteście przeciwko obojętności wobec zła, sprzeciwie wobec ucieczki od prawdy w egoistyczny azyl poezji ${ }^{33}$.

Najistotniejszym gestem, jaki wykonuje podmiot mówiący w liryku Polkowskiego, wydaje się zatem gest zamknięcia przyszłości i empatycznego otwarcia w stronę przeszłości. Zwraca uwagę uruchomiony przez artystę kręg skojarzeń archeologicznych. Bohater tekstu, podobnie jak archeolog, zdziera wierzchnie warstwy ziemi, przedziera się przez pokłady zapomnienia, tak jak archeolog pracuje w śmieciach przeszłości, chciałoby się rzec - na śmietniku historii. Jego zamiarem jest bowiem wydobycie szczątków tych, którzy zostali skazani na zapomnienie, okryci „zmarzliną milczenia”, przysypani wapnem „wiary w potoczystą niepamięć”.

Wyjaśnijmy zatem motywy, jakie nim kierują. Wydaje się, że w analizowany wiersz - podobnie jak zresztą w całą twórczość Polkowskiego - wpisana została koncepcja człowieka jako istoty, która skazana jest na nieustanne dokonywanie wyborów moralnych, na mozolne, samotne odróżnianie dobra od zła. Tylko w ten sposób - tylko dzięki autonomicznym decyzjom moral-

\footnotetext{
${ }^{33}$ Tamże, s. 15.
} 
nym - bohater omawianego wiersza zaświadcza o własnej godności i gruntuje własną tożsamość. Źródłem moralności nie są jednak dla niego normy prawa, lecz poczucie powinności wobec tego, co uznaje za cenne, a więc przede wszystkim wobec innych ludzi, zwłaszcza tych, których los skrzywdził w sposób szczególny. Właśnie dlatego podchodzi on z dużym dystansem do tych wizji przyszłości, które podszyte są utopią - tak skłonny byłbym odczytywać wers o „zamykaniu przyszłości w celi”. Właśnie dlatego opowiada się po stronie pamięci - zdaje sobie sprawę, że tylko ona może mu zapewnić dom, obdarzyć poczuciem zakorzenienia i zacieśnić jego więzy ze wspólnotą. Osią utworu jest opozycja etyki pamięci i utopii nowego świata, spór empatii wobec ofiar reżimu $\mathrm{z}$ wiarą $\mathrm{w}$ świetlaną przyszłość. Ta druga jawi się jako przestrzeń pustki. Poeta opowiada się po stronie tego, co konkretne, ludzkie i bliskie, po stronie tego, co domaga się troski i współczucia. W jednym z wywiadów mówi:

[...] zrozumienie i lojalność wobec polskiego losu nie musi wcale wynikać z rodzinnych czy osobistych przeżyć. Można siedzieć za biurkiem i za pomocą intelektu, wyobraźni, wrażliwości współodczuwać z zesłańcami i do pewnej granicy (bo wobec bólu i śmierci człowiek zawsze pozostaje sam) próbować zrozumieć Inny świat, każdy z innych światów, gdziekolwiek by go Polakom nie zgotowano. Chłonąć solidarnie polskie cierpienie ${ }^{34}$.

Czy można zatem nazwać Jana Polkowskiego narratorem polskiej opowieści? Tomasz Burek twierdzi, że tak:

[...] posiłkując się i manewrując (w sposób specjalny i w ograniczonym zakresie) takimi formami narracyjnymi, jak podróż w czasie i przestrzeni, jak klechda domowa, jak urywki pamiętnika bądź autobiografii, jak okruchy rozbitego zwierciadła: skrawki i odpryski eposu kresowego, jak wreszcie historiografia rozkładu i upadku nieśmiertelnych z pozoru tworów dziejowych, dokonuje Polkowski czegoś niespotykanego w dzisiejszej rzeczywistości literackiej. Odzyskuje dla poezji „wielką opowieść ${ }^{35}$.

Czym więc ostatecznie są poetyckie, dokonywane w wierszach rozmowy Jana Polkowskiego z wielkimi duchami - ze Zbigniewem Herbertem i Tadeuszem Różewiczem? Odnoszę wrażenie, że właśnie jeszcze jednym sposobem

\footnotetext{
${ }^{34}$ Nieprzeparta chętka mówienia prawdy. Rozmowa z Janem Polkowskim, w: W mojej epoce juz wymieram, s. 381.

35 T. BUREK, Opowieść, która..., w: W mojej epoce już wymieram, s. 136.
} 
budowania z okruchów i fragmentów pewnej spójnej, całościowej wizji polskiego losu. Autor Rozmów z Różewiczem daje się wciągnąć starszym kolegom po piórze do rozmowy o niej. Zdaje się podzielać ich przekonanie, że wciąż warto rozmawiać o tym, skąd jesteśmy i jakie doświadczenia kształtowały nas - naszą zbiorową tożsamość. Co więcej: do tej samej rozmowy stara się zaprosić i nas - czytelników jego utworów.

\title{
BIBLIOGRAFIA
}

BOLECKI W.: Poezja polska po 13 grudnia 1981 r., „Almanach Humanistyczny” 1984, nr 1-2. FIUT A.: W potrzasku (O poezji stanu wojennego), w: TEGOŻ, Pytania o tożsamość, Kraków 1995.

Herbert Z.: Pan Cogito, wyd. II poprawione, Wrocław 1993.

Inglot M.: O poezji stanu wojennego, „Język Polski w Szkole Średniej” 1992-1993, nr 1. MielniCZuK J.: Dawanie świadectwa - Herbert, Polkowski, Świetlicki, „Polonistyka” 1999, nr 4. PATRZAŁEK T.: Dwa przesłania, „Polonistyka” 1992, nr 4.

PAWELEC D.: Poezja stanu wojennego. Przymiarka do tematu, „Postscriptum” 1992, nr 2.

POLKOwsKi J.: „Gdy Bóg się waha”. Poezje 1977-2017, red. J.M. Ruszar, Kraków 2017.

POLKOwSKI J.: Rozmowy z Różewiczem, Kraków-Warszawa 2019.

RóżEWICZ T.: I znów zaczyna się przeszłość, wybór i wstęp J. Polkowski, Warszawa 2018.

SŁAwKOwa E.: Jan Polkowski „Przesłanie pana X” - przejmujące świadectwo epoki. Propozycja interpretacyjna dla klasy IV liceum i V technikum, „Język Polski w Szkole Średniej” 1993, z. 1

W mojej epoce już wymieram. Antologia szkiców o twórczości Jana Polkowskiego (19792017), red. J.M. Ruszar, I. Piskorska-Dobrzeniecka, Kraków 2017.

\section{JANA POLKOWSKIEGO WIERSZE-ROZMOWY Z HERBERTEM I RÓŻEWICZEM}

\author{
S t r e s z c z e n i e
}

Poezję Jana Polkowskiego łączy z Herbertem wspólny obu poetom program poezji etycznej, charakterystyczną właśnie dla nich pasję przyświadczania podstawowym wartościom i wiarę w ocalającą moc kultury. Ciekawą grę intertekstualną, zainicjowaną przez młodszego pisarza w wierszu Przestanie pana $X$, pozwala jednak niuansować ten uproszczony obraz. Od początku Przestania pana $X$ jest jasne, że nadzieja, której Polkowski nie odrzuca, wydaje się w jego tekście dużo bardziej problematyczna niż wizja zamieszkania w mitach kultury, jaka wyłania się z utworu autora Potegi smaku. Także obraz wyraźnego antagonizmu Polkowskiego i Róże- 
wicza musi ulec weryfikacji. Polkowski jako autor Rozmów z Różewiczem daje się wciągnąć starszym kolegom po piórze właśnie do rozmowy - o poezji i jej zadaniach, zarysowując nie tylko protokół rozbieżności, ale także szukając tego, co jest mu bliskie w twórczości autora Niepokoju.

Słowa kluczowe: Jan Polkowski; Zbigniew Herbert; Tadeusz Różewicz; intertekstualność.

\section{JAN POLKOWSKI'S POETIC CONVERSATIONS WITH HERBERT AND RÓŻEWICZ}

\section{S u m m a r y}

Jan Polkowski's poetry is linked to Herbert's through the programme of ethical poetry, which is common to both poets, as well as their characteristic passion for admitting fundamental values and faith in the salvational power of culture. However, an interesting intertextual game, initiated by the younger writer in his poem Przestanie pana $X$ [The Envoy of $M r X]$, brings a more nuanced perspective to this simplified image. From the beginning of Przestanie pana $X$, it is clear that hope, which Polkowski does not actually reject, seems to be much more problematic in his text than the vision of living in the myths of culture, which emerges from Herbert's work. The image of Polkowski and Różewicz's clear antagonism must also be verified. As the author of Rozmowy z Różewiczem [Conversations with Różewicz], Polkowski allows his older colleagues to drag him into a conversation about poetry and its tasks, outlining not only certain divergences, but also looking for what is close to his heart in Różewicz's work.

Key words: Jan Polkowski; Zbigniew Herbert; Tadeusz Różewicz; intertextuality.

Translated by Rafat Augustyn 